\title{
Impact of Intellectual capital on Financial Performance and Market Valuation of Firms in India
}

\author{
G. Bharathi Kamath* \\ Department of Economics, University of Mumbai, Ranade Bhavan, Third Floor, Vidyanagari, Kalina \\ Campus, Santacruz (east), Mumbai-400098 \\ *E-mail address: bharathi.g.shan@gmail.com
}

\begin{abstract}
The Objective of this paper is to empirically investigate the impact of intellectual capital(IC) on the financial performance and market valuation of firms in India. Thirty firms from S\&P BSE SENSEX index which consists of 30 firms from across various manufacturing and service sectors. The analysis was carried for a period from FY 2008-2009 to 2012-2013. Multiple linear Regression analysis is used to study the impact of IC on financial performance and market value of these select firms. The paper uses the $\mathrm{VAIC}^{\mathrm{TM}}$ methodology to evaluate the data and finds that the financial performance and market value is indeed influenced by the IC of the firms. This result is crucial for firm's management and policy makers to make IC disclosure and reporting mandatory in firms accounting statements as the stakeholder can get the real picture of the true value of the firm.
\end{abstract}

Keywords: Intellectual capital; financial performance; India; Market value; intangible assets; VAIC ${ }^{\mathrm{TM}}$

\section{INTRODUCTION}

The firm value is generated not only from its physical and financial assets, but also its Intellectual assets which includes, its expenditure on research and development, Human capital, their skills, its organizational structure, policies and relationship that the firm maintains with its customers and suppliers. Many researchers have studied this and attributed the gap between the book value and market value of the firms to intangible assets, intellectual property and intellectual capital (Edvinsson and Malone, 1997). This is observed more specifically in technology and knowledge intensive firms especially information technology, pharmaceutical industry and banking \& financial sectors.

Tangible assets of the firm can be measured, managed and accounted in the book of accounts. However, the same cannot be said about the intellectual capital or intangible assets of the firm. The difficulty in measuring the asset translates itself in non-reporting and low level of disclosure across firms.

Measurement, Management, reporting and disclosure of Intellectual capital has seen a growing interest among researchers across globe. The concept and definition has undergone several changes over decade as there was little consensus on the definition and its components; the measurement techniques suggested also has evolved over years, from use of scorecards, to direct accounting techniques. IC is generally defined as "Knowledge that can be converted into value" (Edvinsson and Malone (1997). Intellectual capital is the sum of 
everything everybody in the company that gives it a competitive edge in the market place. (Stewart, 1997). The other definitions and components and list of measurement techniques was done by Jurckzak (2008).

What is not measured cannot be managed, therefore, the first step towards management of IC is through its measurement, through the systematic literature review Bernard Marr \& others were able to identify five main reasons as to why firms measure the Intellectual capital (Marr, 2003). These were:

1. To help organizations formulate their strategy;

2. Assess strategy execution;

3. Assist in diversification and expansion decisions;

4. Use these as a basis for compensation; and finally

5. To communicate measures to external stakeholders

Once the stakeholders take into account the IC of firms, it starts reflecting in the market value of the firms and helps in furthering the goals of profit maximization. Having stressed on the significance of IC management, measurement and disclosure of IC of firms, it becomes useful to evaluate IC performance of the firms.

The basic objective of this study is to examine the relationship between IC, financial performance and market value of select firms in India. The methodology is adapted from various studies done earlier in different countries (Firer and Williams (2003), Maditinos (2009), Bozbura (2004), Chen et al. (2005), Chang, 2007). The firms are selected from S\&P BSE SENSEX index. It includes firms from manufacturing as well as from services. The impact of IC on financial performance and market value of 30 firms for a 5 year period from FY 2007-2008 to 2012-13 is carried out and the results are analysed. The VAIC components, human capital efficiency, structural capital and capital expended efficiency is also analysed and ranking done on the basis of the VAIC score. This research paper is systematically divided into sections covering review of major literature which has used VAIC method across various economies and sectors, which is presented in the next section, this is followed by detailed research design and methods. The discussion of results and major policy implications along with limitations is given at the end of the paper.

\section{REVIEW OF LITERATURE}

In this section a review of all major literature especially research work, wherein, country specific and firm specific studies using VAIC method have been done is presented. Since there are sufficient studies which have focussed on the theoretical foundations and development of IC framework, the same is not discussed here to avoid duplication and repetition.

Firer and Williams (2003) were among the pioneers to use VAIC method developed by Pulic Ante (2000) to measure the relationship between IC and traditional measures of corporate performance. Their study of 75 South African public traded companies though did not show any significant relationship between the components of VAIC and financial performance, it carved a road for further enquiry in different sectors and countries. The paper by Clarke confirmed direct relationship between IC efficiency and financial performance of Australian publicly listed firms, it was particularly observed that Capital employed efficiency had more impact on performance than Human capital efficiency (Clarke, 2011).

Maditinos (2009) in his study on firms in Greece, found that human capital is significant and positively associated to customer capital. Structural capital was seen to have a higher 
influence especially in non- service industries though the evidence was found in both service and non-service type of industry. Maditinos et al. (2011) researched impact of IC and its components on financial performance and Market Value for 96 firms listed on Athens Stock Exchange (ASE), from four different economic sectors and reported that only human capital component has significant impact. The empirical evidence failed to show the impact of IC on financial performance for the banks listed in Milan stock exchange as reported by Puntillo (2009).

Bozbura (2004) researched firms in turkey and reported that human capital and relational capital have positive relationship with market-book value; it was observed that structural capital was correlated with human and relation capital.

Chen et al. (2005) researched firms listed on Taiwan Stock exchange for the year 19922002. There was sufficient evidence on impact of IC on performance of firms. They also studied the impact of IC with a lag on the performance of the firms, which also confirmed the impact. Another study of Taiwanese firm also observed that profitability and disclosure frequencies of external capital were positively correlated, whereas human capital was negatively correlated (Chang, 2007). Some other studies found a positive relation between IC and profitability and inverse relationship with productivity (Shiu, 2006); another study found a positive relationship between IC and corporate value. (Tseng and Goo, 2005) Researchers from China found empirical evidence for a positive relationship between corporate performance and IC disclosure (Yi \& et al., 2011)

Yet another study on 80 firms listed on Indonesian stock exchange, found that the Intellectual Capital efficiency has a significant effect not only on the current but also future performance of the firms (Pasaribu, 2012). Research on Malaysian firms found that there is a relationship between IC and profitability as reported by Muhammad and Ismail (2009). Another study related to technology intensive listed on Malaysian stock exchange reported by Gan and Saleh (2008), found moderate relationship between IC and profitability \& productivity, however, their research did not show any evidence for impact on market valuation.

The research on firms listed Hong Kong Stock Exchange for the period 2001-05, found no conclusive evidence for any relation between IC and financial performance; however, the researcher finds a very moderate association between IC and profitability (Chan, 2009).

Ren reveals that relational capital is an important factor that positively influences corporate performance, followed by structural capital and human capital in case of firms in China. However, it was found by the researcher that Human capital has an indirect impact on performance through relational capital and structural capital (Ren, 2009).

Kamath (2008) studied Value added by IC (VAIC) for top 25 firms in the drug and pharmaceutical industry in India, for a ten-year period from 1996 to 2006, and its impact on profitability, productivity and market value. The author found evidence for human capital having an impact on IC, though other components and overall IC failed to show any significant empirical impact.

The research on firms in Spain observe that there is an increase in sales growth because of human and structural capital variables. However, the research does not find any significant relation between IC components and productivity or return on assets (Mar1'aDi'ez \& et al, 2010).

Through this review of literature, we can clearly see that almost all studies are related to firms in specific country context. Though some studies were for all industries listed on their stock exchange, some concentrated on one or two industries. However, there were few researches on impact of individual components of IC and their impact on corporate 
performance. There are very few studies that went ahead with inter-country or inter-firm comparisons, primarily because all the studies used the reported data and these vary based on the accounting standards adopted by those countries.

IC and performance of firms seem to be related to some extent if not strongly as observed by most of the studies. Some research indicated that the individual components also have an impact on the performance, however, the results were not uniform and consistent. Most of the studies indicated impact of human capital and structural capital on corporate performance, the results here too could not be generalized.

\section{RESEARCH DESIGN AND METHODOLOGY}

\section{Objectives:}

1. To estimate VAIC ${ }^{\mathrm{TM}}$ and its components for select firms in India for a period of five years 2008-13 and rank them accordingly.

2. To measure the impact of IC on financial performance and market value of firms in India for the above period.

3. To evaluate the relative importance and impact of various components of IC on financial performance and market value.

4. To check whether firms with higher IC are those belonging to service industry or not

Hypothesis:

H1. Firms with greater IC have higher ratios of market-to-book value

This hypothesis indicates that IC is expected to have a positive and significant impact on the market value of the firms.

The other hypothesis that follows this would be

H1a. Firms with greater Human Capital Efficiency (HCE) have higher ratios of marketto-book value.

H1b. Firms with greater Capital Employed Efficiency (CEE) have higher ratios of market-to-book value.

H1c. Firms with greater Structural Capital Efficiency (SCE) have higher ratios of market-to-book value.

On similar lines as in case of hypothesis 1, IC is expected to have a positive and significant influence on the financial performance of the firms.

H2. Firms with greater IC have higher financial performance in terms of profitability and productivity.

H2a. Firms with greater Human Capital Efficiency (HCE) have better financial performance.

H2b. Firms with greater Capital Employed Efficiency (CEE) have better financial performance.

H2c. Firms with greater Structural Capital Efficiency (SCE) have better financial performance.

H3. Knowledge firms have a higher intellectual capital performance (VAIC) than others H3a. Knowledge Firms have higher Human Capital Efficiency (HCE) than other firms firms

H3b. Knowledge Firms have higher Capital Employed Efficiency (CEE) than other

H3c. Knowledge Firms have higher Structural Capital Efficiency (SCE) than other firms 


\section{THE DATA ENVIRONMENT AND METHODOLOGY}

Sample: the firms are selected from the S\&P BSE SENSEX index as available in the year 2014. There are 30 firms from across different sector ranging from banking, pharmaceuticals and automobiles, the detailed break-up of the same is provided in appendixI. These firms are of highest importance as they form a significant share of their respective industries. The empirical investigation is done for a five year period from FY 2008-2009 to 2012-2013, the last year for which the audited financial results are available for all the firms.

The data is collected from the audited published annual reports of the respective companies, extracted through PROWESS database provided by CMIE.

The statistical tools that are used in the methodology are descriptive tools such as mean, median and standard deviation of the variables. A simple correlation analysis is followed up by multiple linear regression analysis on the model specified below, with evaluation and analysis of the same.

Firstly, the correlation analysis is necessary to see if there are strong correlation between the variables of financial performance and market value (dependent variable) and the VAIC and its components (independent variables).

The multiple linear regression analysis would enable determination of the extent or degree of relationship between the variables and also to analyse relative significance of various IC components and the degree of impact the financial performance and market value of the firm.

The data variables are taken from the established framework of VAIC (Ante, 2000)

VAIC is an accepted, consistent and standardized method (Ante, 2001) to measure and compare the IC performance of the firm; the VAIC method enables the firm to measure its value creation efficiency (Ante, 2001, 2002); VAIC has been used across sectors and countries, which enables comparison of results.

In Indian context, since the measurement and management of IC has not yet reached a mature stage, the data collection through primary research is really a difficult proposition. VAIC then becomes the best method that could be adopted since it relies completely on the annual audited financial reports that are published by firms. Therefore the subjectivity held by other measures is reduced to a large extent by this method (Ante, 2002; Bontis et al., 1999; Edvinsson, 1997). As observed in the literature survey, this method is being widely used across countries for evaluating the impact of IC on financial performance of firms, therefore, the present study also uses the VAIC methodology, so that the results can be analysed in the comparative scenario.

Independent variables:

VAIC is the value added intellectual coefficient which comprises of Value added by Human capital efficiency (HCE), value added by efficiency of structural capital (SCE) and value added by capital employed efficiency (CEE)

$$
\begin{gathered}
V A I C_{i}=H C E_{i}+C E E_{i}+S C E_{i} \\
\mathrm{CEE}_{\mathrm{i}}=\frac{V A_{i}}{C E_{i}}
\end{gathered}
$$

Value Added Capital Coefficient for Firm $\left(\mathrm{CEE}_{\mathrm{i}}\right)$; VA $\mathrm{i}$, Value Added for the firm $\mathrm{i}, \mathrm{CE}_{\mathrm{i}}$, book value of the net assets for firm $\mathrm{i}$. The VA is measured by using:

$$
V A_{i}=W_{i}+I_{i}+D P_{i}+D_{i}+T_{i}+M_{i}+R_{i}
$$


where $\mathrm{VA}_{\mathrm{i}}$, Value Added for firm $\mathrm{i}$ computed as sum of; $\mathrm{I}_{\mathrm{i}}$, interest expense; $\mathrm{DP}_{\mathrm{i}}$, depreciation expenses; $D_{i}$, dividends; $T_{i}$, corporate taxes; $M_{i}$, equity of minority shareholders in net income of subsidiaries; $\mathrm{R}_{\mathrm{i}}$, profits retained for the year.

$$
\mathrm{HCE}_{\mathrm{i}}=\frac{V A_{i}}{H C_{i}}
$$

Human Capital Coefficient for the firm i $\left(\mathrm{HCE}_{\mathrm{i}}\right)$; VA $\mathrm{V}_{\mathrm{i}}$, value added for the firmi; $\mathrm{HC}_{\mathrm{i}}$, total salary and wage costs for the firm i.

$$
\begin{aligned}
& \mathrm{SCE}_{\mathrm{i}}=\frac{S C_{i}}{V A_{i}} \\
& S C_{i}=V A_{i}-H C_{i}
\end{aligned}
$$

Structural Capital for the firm i $\left(\mathrm{SCE}_{\mathrm{i}}\right) ; \mathrm{VA}_{\mathrm{i}}$, Value added for the firm $\mathrm{i} ; \mathrm{HC}_{\mathrm{i}}$, total salary and wage costs for the firm i.

Dependent variables:

There are four dependent variables used in the paper MB, ROE, ROA and GS which is elaborated below

Market value (MB): Market capitalization of the firm's shares

Book value (BV): Book value of the shareholders capital

$\mathrm{MB}$ is the ratio of market capitalization to book value of the total shareholders capital of the firm for the given year.

$$
M B=\frac{M \cdot \text { Cap }}{\text { Book value of } N A}
$$

Return on Assets (ROA):

$$
R O A=\frac{N I}{T A}
$$

ROA is a measure of efficiency/productivity of an organization, as it indicates how efficiently the assets of the firms are being used.

Growth of sales (GS):

$G S=$ [(Current year sales-Last year sales) /Last year sales] $* 100$

GS indicates the growth in sales revenues of the firms

Since service firms includes banking firms, these firms income from sale of financial services is taken as sales revenue

Therefore, most of the above indicate whether the firm has been performing profitably as compared to the previous year. 
Productivity (ATO): It is measured using the indicator Asset Turnover Ratio, a ratio of total revenue to total book value of assets as reported in the annual report; and

$$
A T O=\frac{T R}{T A}
$$

Control variables:

The following control variables are used for the study as explained

Return on equity (ROE):

$$
R O E=\frac{N I}{\text { Book value of } S E}
$$

ROE is a measure of an organizations profitability as it indicates how much profits the firm generates from shareholders contribution. It is a ratio of the net income (less preference dividends) divided by book value of total shareholders' equity as reported in annual report;

Size of the Firm (MCAP): - natural log of total market capitalization of the firms;

Leverage (Lev): - total debt divided by book value of total assets as reported in each firm's annual report.

$$
\text { Lev }=\text { Total Debt / BV of TA }
$$

Multiple Linear Regression Model:

Dependent Variable (ROA, ATO, GS or MB) ${ }_{i}=\mathrm{a}_{\mathrm{i}}+\beta_{\mathrm{i} 1} C E E_{i}+\beta_{\mathrm{i} 2} H C E_{i}+\beta_{\mathrm{i} 3} S C E_{i}+$ $\beta_{\mathrm{i} 4} M C A P L_{i}+\beta_{\mathrm{i} 5} L e v_{i}+\beta_{\mathrm{i} 6} R O E_{i}+\varepsilon \mathrm{i}$

Where, $\mathrm{ROA}_{\mathrm{i}}$ is Return on assets; ATO is the measure of productivity; $\mathrm{MB}_{\mathrm{i}}$ is Market to book value; $\mathrm{CEE}_{\mathrm{i}}$ is Capital expended efficiency; $\mathrm{HCE}=$ Human capital efficiency; $\mathrm{SCE}_{\mathrm{i}}=$ Structural Capital Efficiency; $\mathrm{MCAP}_{\mathrm{i}}$ is market capitalization; $\operatorname{Lev}_{\mathrm{i}}$ is the leverage; $\mathrm{ROE}_{\mathrm{i}}$ is the Return on Equity; $\beta_{\mathrm{il}-6}=$ coefficients of variables 1 through 7; and $\varepsilon_{\mathrm{i}}=$ residual term. Measurement of all the variables has been described in detail in the above section.

\section{RESULTS}

Descriptive Statistics:

The mean and standard deviation of all the dependent, independent and control variables is given for a period 2009-13 in Table 1. It is observed that HCE contributes a significant amount to the VAIC- The average VAIC of the 30 firms is 10.4 to 11.7 in various years, of which around 9.6 is contributed by HCE. It is seen that on an average the firms earn around 9-10 percent return on their assets. The market to book value of the firms did not show any specific trend, it is quite fluctuating on an average; and the asset turnover ratio which indicates the productivity ranged between 0.72 and 0.82 across various years. Among the control variables leverage was in between 0.13 and 0.15 and Return on Equity from 0.19 to 
0.22. The standard deviation is highest in HCE and market-to-book value, with in specific trend in other variables.

Table 1. Descriptive Statistics of the Variables: 2009-13.

\begin{tabular}{|c|c|c|c|c|c|c|c|c|c|}
\hline & 2009 & & & 2010 & & & 2011 & & \\
\hline & Average & Median & SD & Average & Median & SD & Average & Median & SD \\
\hline HCE & 9.647 & 6.632 & 13.888 & 9.572 & 6.416 & 12.967 & 9.551 & 6.275 & 12.825 \\
\hline CEE & 0.045 & 0.803 & 5.871 & 1.089 & 0.960 & 0.693 & 1.132 & 0.763 & 0.841 \\
\hline SCE & 0.775 & 0.849 & 0.175 & 0.792 & 0.844 & 0.158 & 0.787 & 0.840 & 0.159 \\
\hline VAIC & 10.467 & 8.143 & 9.587 & 11.453 & 8.359 & 13.346 & 11.469 & 8.073 & 13.412 \\
\hline Leverage & 0.157 & 0.096 & 0.174 & 0.138 & 0.089 & 0.168 & 0.140 & 0.103 & 0.165 \\
\hline Mcap & 12.675 & 12.792 & 0.959 & 13.437 & 13.238 & 0.707 & 13.595 & 13.620 & 0.745 \\
\hline ROA & 0.107 & 0.088 & 0.079 & 0.108 & 0.099 & 0.074 & 0.112 & 0.091 & 0.085 \\
\hline ROE & 0.194 & 0.164 & 0.126 & 0.209 & 0.167 & 0.156 & 0.207 & 0.157 & 0.155 \\
\hline MB & 1.416 & 3.873 & 23.314 & 9.250 & 7.753 & 7.232 & 11.025 & 6.334 & 10.571 \\
\hline ATO & 0.794 & 0.651 & 0.603 & 0.720 & 0.644 & 0.524 & 0.766 & 0.635 & 0.571 \\
\hline GS & 21.436 & 22.089 & 16.761 & 8.879 & 7.441 & 16.203 & 19.859 & 19.513 & 10.128 \\
\hline & 2012 & & & 2013 & & & & & \\
\hline & Average & Median & SD & Average & Median & SD & & & \\
\hline HCE & 9.612 & 6.213 & 14.064 & 9.118 & 5.472 & 14.449 & & & \\
\hline CEE & 1.370 & 0.843 & 1.659 & 0.318 & 0.654 & 3.827 & & & \\
\hline SCE & 0.785 & 0.839 & 0.160 & 0.764 & 0.817 & 0.167 & & & \\
\hline VAIC & 11.767 & 7.833 & 15.520 & 10.200 & 7.127 & 11.216 & & & \\
\hline Leverage & 0.149 & 0.129 & 0.166 & 0.156 & 0.121 & 0.168 & & & \\
\hline Mcap & 13.517 & 13.555 & 0.750 & 13.530 & 13.646 & 0.840 & & & \\
\hline ROA & 0.108 & 0.072 & 0.089 & 0.099 & 0.073 & 0.092 & & & \\
\hline ROE & 0.190 & 0.144 & 0.130 & 0.223 & 0.142 & 0.358 & & & \\
\hline MB & 10.703 & 5.078 & 12.730 & 4.538 & 4.644 & 26.903 & & & \\
\hline ATO & 0.801 & 0.633 & 0.618 & 0.786 & 0.641 & 0.637 & & & \\
\hline GS & 22.273 & 20.963 & 14.516 & 8.471 & 12.105 & 18.621 & & & \\
\hline
\end{tabular}

\section{Correlation:}

The correlation results (not provided due to lack of space) between the independent, control and dependent variables were estimated. A brief summary of the results is given here. The correlation coefficient indicates that ROA has significant (at 1\%) correlation with 
leverage and return on equity (ROE) and some correlation with SCE and CEE. The market-tobook value shows positive significant relation only with HCE, CEE, VAIC and leverage (at $1 \%$ ). The asset turnover ratio (ATO) which indicates productivity of the firms shows significant positive relation with ROE (at $1 \%$ ) and all individual components of VAIC and aggregate VAIC (at 10\%).. Thus, it is observed that all the components of VAIC have shown some significant correlation with any of the dependent variables.

\section{Regression Results:}

The results of all the models of multiple linear regression is presented in Table 2. It can be observed that of the four models fitted, three (ATO, ROA, MB) confirm that they are statistically significant. The fourth model is not statistically significant, indicating that growth of sales do not have any influence or impact on the dependent variable. The adjusted $\mathrm{R}^{2}$, is very high in case of market valuation (0.931) and very low in case of growth of sales (.017). In the first model (ROA), four independent variables (HCE, SCE, Lev, ROE) are statistically significant at $\rho<0.01$, of which SCE and Lev shows a negative sign and the other variables are with positive sign. The second model (ATO), shows statistical significance only for one variable i.e. ROE at $\rho<0.10$, the sign is positive. In the third model (MB), there are two variables which are statistically significant, $\mathrm{CEE}$ and ROE, both at $\rho<0.01$ with both having a positive. In the fourth model (GS), none of the independent variables are statistically significant.

Table 2. Results of Multiple Linear Regression.

\begin{tabular}{|c|c|c|c|c|c|c|c|}
\hline $\begin{array}{c}\text { Dependent } \\
\text { Variables à }\end{array}$ & \multicolumn{2}{|c|}{ Profitability (ROA) } & \multicolumn{2}{c|}{ Productivity (ATO) } & \multicolumn{2}{c|}{$\begin{array}{c}\text { Market Valuation } \\
\text { (MB) }\end{array}$} & $\begin{array}{c}\text { Growth in Sales } \\
\text { revenue/Income } \\
\text { (GS) }\end{array}$ \\
\hline $\mathrm{N}$ & \multicolumn{2}{|c|}{30} & \multicolumn{2}{c|}{30} & \multicolumn{2}{c|}{30} & \multicolumn{2}{c|}{0.931} \\
\hline Adjusted R
\end{tabular}

Ranking of firms based on their VAIC in the year 2012-13:

VAIC for all the firms in the study is estimated as per the procedure specified above and then all the firms are ranked based on their VAIC score for the year 2012-13. The Table 3 
gives the ranking of the firms on the VAIC. It is observed that there are 3 firms belonging to service sector and 2 to manufacturing sector among the top 5 rankers; however, there are only 6 firms from service in the top 15. The evidence that service sector has higher IC than manufacturing therefore is not substantial and results inconclusive. The difference in performance among the highest ranked firm and lowest ranked firm is also observed to be substantial (around 20 times) even in the sample of top 30 firms. This result goes very far in explaining the range when all the firms would be studied. Another important observation that emerges is that among the top 10 firms ranking, only 3 belongs to the state-owned enterprise. This is an indication that private firms are giving more importance to human capital development that public sector firms. When ranked on the basis of HCE, CEE and SCE (not given due to shortage of space), the ranking does not seem to change much for HCE and SCE. However, in terms of CEE, the ranking changes substantially, HUL tops the chart followed by HDFC bank and TCS. The public sector seems to go down below in this ranking as only one public sector i.e. State Bank of India.

Table 3. VAIC Ranking of companies- Sorted on the 2012-13 Ranks.

\begin{tabular}{|c|c|c|c|c|c|c|c|c|c|c|c|c|}
\hline & 2009 & & & & 2010 & & & & 2011 & & & \\
\hline $\begin{array}{c}\text { Company } \\
\text { Name }\end{array}$ & HCE & CEE & SCE & VAIC & HCE & CEE & SCE & VAIC & HCE & CEE & SCE & VAIC \\
\hline $\begin{array}{c}\text { Housing } \\
\text { Development } \\
\text { Finance Corpn. } \\
\text { Ltd. } \\
\end{array}$ & 75.760 & -31.191 & 0.987 & 45.555 & 73.303 & 3.246 & 0.986 & 77.535 & 70.325 & 3.669 & 0.986 & 74.981 \\
\hline Coal India Ltd. & 14.772 & 1.714 & 0.932 & 17.418 & 18.668 & 0.988 & 0.946 & 20.602 & 21.234 & 1.171 & 0.953 & 23.358 \\
\hline Axis Bank Ltd. & 11.147 & 0.715 & 0.910 & 12.773 & 9.536 & 0.826 & 0.895 & 11.257 & 9.686 & 0.759 & 0.897 & 11.342 \\
\hline $\begin{array}{c}\text { Reliance } \\
\text { Industries Ltd. }\end{array}$ & 11.425 & 0.255 & 0.912 & 12.593 & 15.088 & 0.210 & 0.934 & 16.232 & 16.631 & 0.260 & 0.940 & 17.831 \\
\hline $\begin{array}{l}\text { I C I C I Bank } \\
\text { Ltd. }\end{array}$ & 15.566 & 0.916 & 0.936 & 17.417 & 13.126 & 0.634 & 0.924 & 14.684 & 9.540 & 0.768 & 0.895 & 11.202 \\
\hline $\begin{array}{c}\text { Bharti Airtel } \\
\text { Ltd. }\end{array}$ & 8.679 & 0.726 & 0.885 & 10.290 & 10.485 & 0.789 & 0.905 & 12.179 & 10.629 & 0.500 & 0.906 & 12.035 \\
\hline $\begin{array}{l}\text { H D F C Bank } \\
\text { Ltd. }\end{array}$ & 6.744 & 1.791 & 0.852 & 9.387 & 6.433 & 0.937 & 0.845 & 8.215 & 6.525 & 1.145 & 0.847 & 8.517 \\
\hline $\begin{array}{l}\text { G A I L (India) } \\
\text { Ltd. }\end{array}$ & 9.450 & 0.500 & 0.894 & 10.845 & 9.425 & 0.454 & 0.894 & 10.774 & 9.200 & 0.528 & 0.891 & 10.620 \\
\hline $\begin{array}{l}\text { Bajaj Auto } \\
\text { Ltd. } \\
\end{array}$ & 3.009 & 0.994 & 0.668 & 4.671 & 5.283 & 1.296 & 0.811 & 7.389 & 10.061 & 2.831 & 0.901 & 13.793 \\
\hline I T C Ltd. & 6.837 & 0.592 & 0.854 & 8.282 & 7.454 & 0.686 & 0.866 & 9.006 & 7.747 & 0.735 & 0.871 & 9.353 \\
\hline $\begin{array}{c}\text { Hindustan } \\
\text { Unilever Ltd. }\end{array}$ & 3.690 & 1.977 & 0.729 & 6.396 & 3.651 & 2.459 & 0.726 & 6.836 & 4.265 & 2.120 & 0.766 & 7.150 \\
\hline N T P C Ltd. & 6.903 & 0.351 & 0.855 & 8.108 & 7.327 & 0.369 & 0.864 & 8.559 & 6.832 & 0.339 & 0.854 & 8.025 \\
\hline $\begin{array}{l}\text { State Bank Of } \\
\text { India } \\
\end{array}$ & 6.879 & 1.017 & 0.855 & 8.750 & 5.850 & 1.650 & 0.829 & 8.329 & 4.974 & 1.039 & 0.799 & 6.812 \\
\hline $\begin{array}{c}\text { Hero } \\
\text { Motocorp Ltd. }\end{array}$ & 5.379 & 2.951 & 0.814 & 9.144 & 6.399 & 1.783 & 0.844 & 9.026 & 5.560 & 1.741 & 0.820 & 8.121 \\
\hline $\begin{array}{l}\text { Maruti Suzuki } \\
\text { India Ltd. }\end{array}$ & 6.519 & 0.576 & 0.847 & 7.941 & 10.058 & 1.127 & 0.901 & 12.086 & 6.813 & 0.685 & 0.853 & 8.350 \\
\hline $\begin{array}{c}\text { Tata Power } \\
\text { Co. Ltd. }\end{array}$ & 6.982 & 0.338 & 0.857 & 8.177 & 7.358 & 0.274 & 0.864 & 8.496 & 6.025 & 0.305 & 0.834 & 7.163 \\
\hline $\begin{array}{c}\text { Oil \& Natural } \\
\text { Gas Corpn. } \\
\text { Ltd. }\end{array}$ & 7.929 & 0.827 & 0.874 & 9.629 & 6.973 & 0.740 & 0.857 & 8.570 & 6.945 & 0.698 & 0.856 & 8.499 \\
\hline $\begin{array}{c}\text { Hindalco } \\
\text { Industries Ltd. }\end{array}$ & 6.213 & 0.417 & 0.839 & 7.468 & 4.700 & 0.413 & 0.787 & 5.900 & 4.401 & 0.395 & 0.773 & 5.569 \\
\hline $\begin{array}{c}\text { Mahindra \& } \\
\text { Mahindra Ltd. }\end{array}$ & 2.142 & 0.779 & 0.533 & 3.454 & 3.493 & 1.135 & 0.714 & 5.342 & 3.752 & 2.255 & 0.733 & 6.741 \\
\hline Tata Steel Ltd. & 5.146 & 1.095 & 0.806 & 7.047 & 5.152 & 1.055 & 0.806 & 7.013 & 5.509 & 1.200 & 0.818 & 7.528 \\
\hline Cipla Ltd. & 5.003 & 0.308 & 0.800 & 6.111 & 5.745 & 0.412 & 0.826 & 6.983 & 3.984 & 0.327 & 0.749 & 5.060 \\
\hline $\begin{array}{l}\text { Sesa Sterlite } \\
\text { Ltd. }\end{array}$ & 36.476 & 4.257 & 0.973 & 41.705 & 26.791 & 0.983 & 0.963 & 28.737 & 31.258 & 2.657 & 0.968 & 34.883 \\
\hline
\end{tabular}




\begin{tabular}{|c|c|c|c|c|c|c|c|c|c|c|c|c|}
\hline $\begin{array}{c}\text { Larsen \& } \\
\text { Toubro Ltd. }\end{array}$ & 3.739 & 0.986 & 0.733 & 5.458 & 3.816 & 1.258 & 0.738 & 5.812 & 3.467 & 1.183 & 0.712 & 5.361 \\
\hline $\begin{array}{c}\text { Tata } \\
\text { Consultancy } \\
\text { Services Ltd. }\end{array}$ & 1.477 & 3.188 & 0.323 & 4.987 & 1.571 & 2.619 & 0.363 & 4.553 & 1.607 & 2.100 & 0.378 & 4.085 \\
\hline $\begin{array}{c}\text { Dr. Reddy'S } \\
\text { Laboratories } \\
\text { Ltd. }\end{array}$ & 3.095 & 0.490 & 0.677 & 4.262 & 3.392 & 0.805 & 0.705 & 4.902 & 2.749 & 0.551 & 0.636 & 3.936 \\
\hline $\begin{array}{l}\text { Bharat Heavy } \\
\text { Electricals Ltd. }\end{array}$ & 2.769 & 0.599 & 0.639 & 4.006 & 2.089 & 0.850 & 0.521 & 3.460 & 2.795 & 0.714 & 0.642 & 4.151 \\
\hline $\begin{array}{c}\text { Sun } \\
\text { Pharmaceutical } \\
\text { Inds. Ltd. } \\
\end{array}$ & 9.744 & 0.552 & 0.897 & 11.193 & 6.839 & 0.696 & 0.854 & 8.388 & 7.669 & 0.558 & 0.870 & 9.096 \\
\hline $\begin{array}{c}\text { Tata Motors } \\
\text { Ltd. }\end{array}$ & 2.720 & 0.999 & 0.632 & 4.351 & 3.616 & 1.691 & 0.723 & 6.030 & 2.994 & 0.606 & 0.666 & 4.265 \\
\hline Wipro Ltd. & 1.467 & 1.545 & 0.318 & 3.330 & 1.703 & 1.238 & 0.413 & 3.354 & 1.577 & 1.200 & 0.366 & 3.144 \\
\hline Infosys Ltd. & 1.754 & 1.086 & 0.430 & 3.270 & 1.835 & 1.043 & 0.455 & 3.333 & 1.767 & 0.907 & 0.434 & 3.108 \\
\hline
\end{tabular}

\begin{tabular}{|c|c|c|c|c|c|c|c|c|}
\hline \multicolumn{2}{|l|}{2012} & \multirow[b]{2}{*}{ CEE } & \multirow[b]{2}{*}{ SCE } & \multirow[b]{2}{*}{ VAIC } & \multirow{2}{*}{$\begin{array}{l}2013 \\
\text { HCE } \\
\end{array}$} & \multirow[b]{2}{*}{ CEE } & \multirow[b]{2}{*}{ SCE } & \multirow[b]{2}{*}{ VAIC } \\
\hline $\begin{array}{l}\text { Company } \\
\text { Name }\end{array}$ & HCE & & & & & & & \\
\hline $\begin{array}{c}\text { Housing } \\
\text { Development } \\
\text { Finance Corpn. } \\
\text { Ltd. }\end{array}$ & 79.773 & 9.122 & 0.987 & 89.883 & 80.908 & 19.799 & 0.988 & 62.096 \\
\hline Coal India Ltd. & 28.251 & 1.206 & 0.965 & 30.422 & 31.424 & 1.002 & 0.968 & 33.394 \\
\hline Axis Bank Ltd. & 10.907 & 1.573 & 0.908 & 13.388 & 11.695 & 1.398 & 0.914 & 14.007 \\
\hline $\begin{array}{c}\text { Reliance } \\
\text { Industries Ltd. }\end{array}$ & 14.674 & 0.256 & 0.932 & 15.862 & 12.418 & 0.253 & 0.919 & 13.590 \\
\hline $\begin{array}{c}\text { I C I C I Bank } \\
\text { Ltd. }\end{array}$ & 10.058 & 0.901 & 0.901 & 11.860 & 10.650 & 1.038 & 0.906 & 12.594 \\
\hline $\begin{array}{c}\text { Bharti Airtel } \\
\text { Ltd. }\end{array}$ & 11.207 & 0.479 & 0.911 & 12.598 & 10.857 & 0.511 & 0.908 & 12.276 \\
\hline $\begin{array}{c}\text { H D F C Bank } \\
\text { Ltd. }\end{array}$ & 7.770 & 4.059 & 0.871 & 12.700 & 8.470 & 2.744 & 0.882 & 12.096 \\
\hline $\begin{array}{c}\text { G A I L (India) } \\
\text { Ltd. }\end{array}$ & 10.496 & 0.427 & 0.905 & 11.828 & 10.433 & 0.386 & 0.904 & 11.724 \\
\hline $\begin{array}{l}\text { Bajaj Auto } \\
\text { Ltd. }\end{array}$ & 8.765 & 1.706 & 0.886 & 11.357 & 7.929 & 1.978 & 0.874 & 10.781 \\
\hline I T C Ltd. & 8.376 & 0.785 & 0.881 & 10.041 & 9.016 & 0.714 & 0.889 & 10.618 \\
\hline $\begin{array}{c}\text { Hindustan } \\
\text { Unilever Ltd. }\end{array}$ & 4.293 & 2.600 & 0.767 & 7.660 & 4.909 & 4.019 & 0.796 & 9.725 \\
\hline N T P C Ltd. & 6.656 & 0.322 & 0.850 & 7.828 & 7.764 & 0.319 & 0.871 & 8.954 \\
\hline $\begin{array}{l}\text { State Bank Of } \\
\text { India }\end{array}$ & 5.854 & 1.293 & 0.829 & 7.977 & 6.239 & 1.539 & 0.840 & 8.618 \\
\hline $\begin{array}{c}\text { Hero } \\
\text { Motocorp Ltd. }\end{array}$ & 6.416 & 2.038 & 0.844 & 9.297 & 5.486 & 1.808 & 0.818 & 8.112 \\
\hline $\begin{array}{l}\text { Maruti Suzuki } \\
\text { India Ltd. }\end{array}$ & 5.106 & 0.497 & 0.804 & 6.408 & 5.696 & 0.618 & 0.824 & 7.138 \\
\hline $\begin{array}{l}\text { Tata Power } \\
\text { Co. Ltd. }\end{array}$ & 6.011 & 0.325 & 0.834 & 7.169 & 5.973 & 0.309 & 0.833 & 7.115 \\
\hline $\begin{array}{c}\text { Oil \& Natural } \\
\text { Gas Corpn. } \\
\text { Ltd. }\end{array}$ & 8.396 & 0.692 & 0.881 & 9.969 & 5.458 & 0.616 & 0.817 & 6.890 \\
\hline $\begin{array}{c}\text { Hindalco } \\
\text { Industries Ltd. }\end{array}$ & 4.822 & 0.496 & 0.793 & 6.110 & 4.958 & 0.457 & 0.798 & 6.213 \\
\hline $\begin{array}{c}\text { Mahindra \& } \\
\text { Mahindra Ltd. }\end{array}$ & 3.590 & 1.415 & 0.721 & 5.726 & 3.824 & 1.375 & 0.739 & 5.938 \\
\hline Tata Steel Ltd. & 5.406 & 1.520 & 0.815 & 7.742 & 4.260 & 0.691 & 0.765 & 5.717 \\
\hline Cipla Ltd. & 3.327 & 0.421 & 0.699 & 4.447 & 3.380 & 0.495 & 0.704 & 4.579 \\
\hline $\begin{array}{c}\text { Sesa Sterlite } \\
\text { Ltd. }\end{array}$ & 15.328 & 2.146 & 0.935 & 18.409 & 3.490 & 0.347 & 0.713 & 4.551 \\
\hline $\begin{array}{c}\text { Larsen \& } \\
\text { Toubro Ltd. }\end{array}$ & 3.024 & 0.657 & 0.669 & 4.350 & 3.006 & 0.803 & 0.667 & 4.476 \\
\hline $\begin{array}{c}\text { Tata } \\
\text { Consultancy } \\
\text { Services Ltd. }\end{array}$ & 1.734 & 1.967 & 0.423 & 4.124 & 1.679 & 2.020 & 0.404 & 4.104 \\
\hline
\end{tabular}




\begin{tabular}{|c|c|c|c|c|c|c|c|c|c|}
$\begin{array}{c}\text { Dr. Reddy'S } \\
\text { Laboratories } \\
\text { Ltd. }\end{array}$ & 2.828 & 0.559 & 0.646 & 4.033 & & 2.835 & 0.504 & 0.647 & 3.986 \\
\hline $\begin{array}{c}\text { Bharat Heavy } \\
\text { Electricals Ltd. }\end{array}$ & 3.045 & 0.567 & 0.672 & 4.284 & & 2.838 & 0.434 & 0.648 & 3.919 \\
\hline $\begin{array}{c}\text { Sun } \\
\text { Pharmaceutical } \\
\text { Inds. Ltd. }\end{array}$ & 6.477 & 0.515 & 0.846 & 7.838 & & 2.607 & 0.156 & 0.616 & 3.379 \\
\hline $\begin{array}{c}\text { Tata Motors } \\
\text { Ltd. }\end{array}$ & 2.459 & 0.495 & 0.593 & 3.547 & & 2.159 & 0.486 & 0.537 & 3.183 \\
\hline $\begin{array}{c}\text { Wipro Ltd. } \\
\text { Wipros Ltd. }\end{array}$ & 1.506 & 1.126 & 0.336 & 2.968 & & 1.504 & 1.301 & 0.335 & 3.140 \\
\hline Infosys L & 0.933 & 0.446 & 3.185 & & 1.668 & 1.008 & 0.400 & 3.076 \\
\hline
\end{tabular}

\section{DISCUSSION OF RESULTS}

It was found in the regression results that profitability of the select BSE index firms is strongly affected by its efficiency of intellectual capital (VAIC). Among the components, human capital and structural capital of the firm have greater influence on profitability than capital expended. It is also observed that Structural capital influences negatively on profitability. Among the control variables, Leverage and ROE also has an influence on firm's profitability. It is observed that firms having lower leverage have higher profitability. Whereas, ROE and ROA move in the same direction, firms with higher return on its equity is seen to be more profitable than others. Size of firm does not influence the profitability. This is a very important and significant conclusion as it shows that intellectual capital does have a role in the performance of the firms. The stakeholders now have to account for the contribution of intangible also while looking at the value and performance of the firm.

The second aspect that was observed that the overall Productivity of the firm is also majorly affected by the IC and its efficiency. The individual components of IC were seen to be statistically not significant, however, overall model showed a good fit. Only ROE in the control variables showed a statistically significant influence on the productivity of the firms. Leverage and size is seen not to have any impact on the productivity of the firms in India. Therefore, we can say that there is no empirical evidence of IC components influencing the productivity of firms and the said firms look more at their tangible assets for value creation.

The third model related to market valuation and its relation with efficiency of IC, there was a clear evidence regarding the overall impact. Among the components of IC, it was only capital expended efficiency which showed influencing market valuation of the firms. There was no evidence on Human capital and structural capital influence on market valuation. Among the control variables, Leverage and size of the firm also did not have any impact on market valuation of firms. Only ROE seems to have an impact on the market valuation, firms with higher ROE also has higher market value. It is observed that though intangibles do have an overall impact on the market valuation of firms, its only capital expended that finally has highest impact.

The last model that was fitted was related to growth of sales, the empirical evidence does not support even a minute relation or impact of intangibles on growth of sales. The overall model is a bad fit, even the components of IC were seen to be statistically insignificant impact. It is to be noted here that Morteza et al. 2014; Abbasali, 2013 in their research showed impact of IC on sales, which in Indian context seems to completely non-existent.

Overall, it was observed that the size of the firm had no significant impact on any aspect of financial performance and market valuation. Leverage had influence only on profitability, 
but did not show any major influence on productivity and market valuation. The return on equity showed clear influence on profitability, productivity as well as market valuation. None of the control variables had any influence on growth of sales, the result is similar as in case of other independent variables.

\section{CONCLUSIONS}

This paper set out to analyse and evaluate the relationship between efficiency of IC and its components on financial performance viz. profitability, productivity and growth of sales/Income and market valuation. The objective was to study 30 firms of "BSE Index" traded on Bombay Stock Exchange (BSE). The study was done for the FY 2008-09 to 201213. VAIC introduced by Pulic Ante was used as a tool to measure and evaluate the efficiency of IC and its components. The empirical evidence found interesting results, it was observed that profitability, productivity and market valuation are influenced by overall IC efficiency. However, the impact of individual components was seen to be varied on financial performance and market valuation. There are some limitations of the present research in terms of number of firms studied and time period of study, which can be utilized as an opportunity for future research. Sector or industry specific studies can be carried out for a time series data to understand the phenomenon across sectors and industries and get a comparative picture.

Earlier research work in done in pharmaceutical industries in India, had evidence to suggest that IC did not have any major influence on financial performance and market valuation of firms (Kamath, 2008). Several other studies (Firer and Williams, 2003; Puntillo, 2009; Chan, 2009) also found evidence that IC and efficiency are not significantly related. Some research works have reported evidence on IC impact on financial performance and market valuation (Chen et al. (2005), Tan et al. (2007), Pal and Soriya (2012))

This research conclusions are very significant, as the measurement, management and reporting of IC by firms is voluntary in India. If the measurement and disclosure is made mandatory, then the stakeholders would get a clearer picture about the true performance of the firms and would enable them towards better decision making. The diminishing role of tangibles in the value creation of firms and the ever increasing significance of intangibles must be taken into account by the policy makers as well as the managers of the firms on a priority basis.

\section{Bibliographical Notes}

Dr. G. Bharathi Kamath (PhD from Osmania University, Hyderabad, India) is currently Associate Professor in the Department of Economics at University of Mumbai, India. Her research interests are in the areas of intangible assets, intellectual capital and intellectual property rights, with a current focus on the industry based studies. She has several national and international publications to her credit. 


\section{References}

[1] Abbasali Pouraghajan, et al, "Impact of Intellectual Capital on Market Value and Firms' Financial Performance", World of Sciences Journal, Vol.1 No. 12, pp.197-208.

[2] Ante, Pulic, (2000), "VAIC ${ }^{\mathrm{TM}}$ an Accounting tool for IC management", International Journal of Technology Management, Vol. 20, No. 5-8, pp. 702-714.

[3] Ante, Pulic, (2001), "Value Creation Efficiency Analysis of Croatian Banks 19962000”, accessed in March 2013 available on http://www.vaic-on.net/

[4] Ante, Pulic, (2002), "Do we know if we create or destroy value?" accessed in March 2013, available on http://www.vaic-on.net.

[5] Bontis, N., (1999), "Managing Organizational Knowledge by Diagnosing Intellectual Capital: Framing and Advancing the State of the Field", Intellectual Journal of Technology Management, Vol. 18, No. 5/6/7/8, pp. 433-462.

[6] Bozbura, F., (2004), "Measurement and application of intellectual capital in Turkey", The Learning Organization, Vol. 11, No. 4-5, pp.357 - 367.

[7] Chan, K. H., (2009), "Impact of intellectual capital on organisational performance: An empirical study of companies in the Hang Seng Index (Part 1 \& 2)", The Learning Organization, Vol. 16, No. 1, pp. 4-21 \& pp.22-39.

[8] Chang Yuan-Chieh, Huo-Tsiang Chang, (2007), "Firm attributes and intellectual capital disclosure: evidences from IPO prospectuses in Taiwan", accessed in March 2013 available on http://120.107.180.177/1832/9801/9801-13pa.pdf

[9] Chen, M.C., Cheng, S.J., Hwang, Y., (2005), "An empirical investigation of the relationship between intellectual capital and firms' market value and financial performance", Journal of Intellectual capital, Vol. 6, No.2, pp.159-76.

[10] Clarke Martin, Seng, D., and Whiting, R. H., (2011), "Intellectual capital and firm performance in Australia", Journal of Intellectual Capital, Vol. 12, No. 4, pp.505-530.

[11] Edvinsson, L., Malone, M.S., (1997), Intellectual Capital: Realizing Your Company's True Value by Finding Its Hidden Brainpower, Harper Business, New York, NY

[12] Firer, S., and Williams M.S., (2003) "Intellectual capital and traditional measures of corporate performance", Journal of Intellectual Capital, Vol. 4, No. 3, pp.348-360.

[13] Gan, K., and Saleh, Z., (2008), "Intellectual capital and corporate performance of technology-intensive companies", Asian Journal of Business and Accounting, Vol. 1, No. 1, pp. 113-130.

[14] Jurckzak, (2008), "Intellectual Capital Measurement Methods", Economics and Organization of Enterprise Vol. 1, No. 1, pp. 37 - 45.

[15] Kamath, G. B., (2008), "Intellectual capital and corporate performance in Indian pharmaceutical industry", Journal of Intellectual Capital, Vol. 9, No. 4, pp. $684-704$.

[16] Maditinos, D., Chatzoudes, D., Tsairidis, G., and Theriou, G., (2011), "The impact of intellectual capital on firms' market value and financial performance", Journal of Intellectual Capital, Vol. 12, No. 1, pp. 132-151. 
[17] Maditinos, D., et al., (2009), "Intellectual capital and business performance: an empirical study for the Greek listed companies", 7th International Conference on Accounting and Finance in Transition, July, pp.23-25.

[18] Mar1'aD1'ez Jose, Magda Lizet Ochoa, M. BegonªPrieto and Alicia Santidria'n, (2010), "Intellectual capital and value creation in Spanish firms", Journal of Intellectual Capital, Vol. 11, No. 3, pp. 348-367.

[19] Marr, B., Dina G., and Andy N., (2003), "Why do firms measure their intellectual capital?", Journal of Intellectual Capital, Vol. 4, No. 4, pp. 441-464.

[20] Morteza Piri,Milad Jasemi,Majid Abdi, (2013) "Intellectual capital and knowledge management in the Iranian space industries",VINE, Vol. 43, No. 3, pp.341 - 356

[21] Muhammad, N.M.N. and Ismail M.K.A., (2009), "Intellectual capital efficiency and firm's performance: Study on Malaysian financial sectors", International Journal of Economics and Finance, Vol. 1, No. 2, pp. 206-212.

[22] Pal Karam and Sushila Soriya, (2012), "IC performance of Indian pharmaceutical and textile industry", Journal of Intellectual Capital, Vol. 13 No. 1, pp. 120-137

[23] Pasaribu, H., Dian Indri Purnamasari, and Indri Tri Hapsari, (2012), "The role of corporate intellectual capital", American International Journal of Contemporary Research, Vol. 2, No. 9, accessed in March 2013 available on http://www.aijcrnet.com/journals/Vol_2_No_9_September_2012/19.pdf.

[24] Puntillo, P. (2009), "Intellectual capital and business performance: Evidence from Italian banking industry", Electronic Journal of Corporate Finance, Vol. 4, No. 12, pp. 96-115.

[25] Ren, J.-yi and R.J.-yi, (2009), "The empirical study on the relationship between corporate intellectual capital and corporate performance",16th International Conference on Industrial Engineering and Engineering Management, Vol. 40, No. 6, pp. 537-541.

[26] Shiu, H., (2006), "The Application of the Value Added Intellectual Coefficient to Measure Corporate Performance: Evidence from Technological Firms", International Journal of Management, Vol. 23, No. 2, pp. 356-365.

[27] Stewart, T. (1997) Intellectual Capital: The New Wealth Of Organizations, Nicholas Brealey Publishing, Business Digest, New York

[28] Sullivan, (2000), Value-driven Intellectual Capital: How to Convert Intangible Corporate Assets into Market Value, John Wiley and Sons, Toronto, Canada

[29] Tan Hong P., Plowman, D., and Hancock, P., (2007), "Intellectual capital and financial returns of companies", Journal of Intellectual Capital, Vol. 8, No. 1, pp. 7695. http://dx.doi.org/10.1108/1469193071071507

[30] Tseng, C.Y., and Goo, Y.J. (2005), "Intellectual Capital and Corporate Value in an Emerging Economy: Empirical Study of Taiwanese Manufacturers", $R \quad \& \quad D$ Management, Vol. 35, No.2, pp.187-201.

[31] Yi, An, Davey, Howard and Eggleton, Ian R. C., (2011), "The effects of industry type, company size and performance on Chinese companies' IC disclosure: a research note”, Australasian Accounting Business and Finance Journal, Vol. 5, No. 3, pp. 107116. Accessed in March 2013 available on http://ro.uow.edu.au/aabfj/vol5/iss3/8/. 
Appendix I

Classification of companies in S \& P BSE SENSEX Index

\begin{tabular}{|c|c|}
\hline Banking and Financial Services (5) & Axis Bank, HDFC, HDFC Bank, ICICI Bank, SBI \\
\hline Automobiles (5) & $\begin{array}{c}\text { Bajaj Auto, Hero MotoCorp, Mahindra \& } \\
\text { Mahindra, Maruti Suzuki, Tata Motors }\end{array}$ \\
\hline Telecommunications (1) & Bharti Airtel \\
\hline Heavy Industries (5) & BHEL, Hindalco Inds, L\&T, Tata Steel, SSLT \\
\hline Pharmaceutical (3) & Cipla, Dr Reddys Lab, Sun Pharma \\
\hline Petroleum, Oil and Energy (6) & $\begin{array}{c}\text { Coal India, Gail India, NTPC, ONGC, RIL, Tata } \\
\text { Power }\end{array}$ \\
\hline FMCG (2) & Hindustan Unilever, ITC \\
\hline IT and ITES (3) & Infosys, TCS, Wipro, \\
\hline
\end{tabular}

( Received 02 February 2015; accepted 14 February 2015 ) 